\title{
What is new and what is nationalist about Europe's new nationalism? Explaining the rise of the far right in Europe
}

Article

Accepted Version

Halikiopoulou, D. and Vlandas, T. (2019) What is new and what is nationalist about Europe's new nationalism? Explaining the rise of the far right in Europe. Nations and Nationalism, 25 (2). pp. 409-434. ISSN 1469-8129 doi:

https://doi.org/10.1111/nana.12515 Available at https://centaur.reading.ac.uk/80296/

It is advisable to refer to the publisher's version if you intend to cite from the work. See Guidance on citing.

To link to this article DOI: http://dx.doi.org/10.1111/nana.12515

Publisher: Wiley-Blackwell

All outputs in CentAUR are protected by Intellectual Property Rights law, including copyright law. Copyright and IPR is retained by the creators or other copyright holders. Terms and conditions for use of this material are defined in the End User Agreement.

www.reading.ac.uk/centaur 
Central Archive at the University of Reading

Reading's research outputs online 


\section{NATIONS AND NATIONALISM}

IOURNAL OF THE ASSOCIATION FOR THE STUDY OF ETHNICITY AND NATIONALISM

\section{What is new and what is nationalist about Europe's new nationalism? Explaining the rise of the far right in Europe}

\begin{tabular}{|c|c|}
\hline Journal: & Nations and Nationalism \\
\hline Manuscript ID & Draft \\
\hline Wiley - Manuscript type: & Invited Submission \\
\hline Discipline: & Comparative Politics/Political Science \\
\hline Keywords: & $\begin{array}{l}\text { Far Right / Radical Right / Populist Right, Immigration/Migration, European } \\
\text { Union/ European Identity / Europe, Economic Nationalism, Cultural } \\
\text { Nationalism }\end{array}$ \\
\hline \multicolumn{2}{|l|}{ Other Keywords: } \\
\hline Abstract: & $\begin{array}{l}\text { Far right parties are on the rise across Europe. Their shared populist } \\
\text { rhetoric, emphasis on sovereignty and policies that promote a 'national } \\
\text { preference' has facilitated the term 'the new nationalism'. According to an } \\
\text { emerging consensus, this new nationalism is primarily a demand-side } \\
\text { phenomenon triggered by cultural grievances, i.e. a cultural backlash, } \\
\text { driven by those on the wrong end of a new transnational cleavage. This } \\
\text { explanation we argue, tends to overlook important variations across } \\
\text { countries and across time. As such, in this article, we contest the view that } \\
\text { the 'new nationalism' is a linear and coherent phenomenon best } \\
\text { understood as a cultural backlash. Specifically, our argument is threefold: } \\
\text { (1) it is important to conceptually distinguish between populism, } \\
\text { nationalism and the far right in order to draw meaningful conclusions about } \\
\text { the extent to which this phenomenon is linear, coherent and comparable } \\
\text { across cases; ( } 2 \text { ) voters' economic concerns remain pivotal within the } \\
\text { context of the transnational cleavage, entailing that voting behavior is } \\
\text { structured by two dimensions of contestation; (3), the explanatory power } \\
\text { of nationalism is in the supply, i.e. the ways in which parties use } \\
\text { nationalism strategically in an attempt to broaden their appeal. }\end{array}$ \\
\hline
\end{tabular}




\section{What is new and what is nationalist about Europe's new nationalism? Explaining the rise of the far right in Europe}

\section{Introduction}

Political parties pledging to speak on behalf of the 'pure people', restore national sovereignty, 'take back control' from supra-national institutions and promote the 'national preference' through strict immigration and citizenship policies are often described as part of a phenomenon termed 'the new nationalism' (Economist 2016). In other words, this phenomenon, understood as fairly new and uniform, is characterised by the rise of parties whose key features include nationalism and populism. Examples include the French Front National (FN) (now Rassemblement National), the Dutch Freedom Party (PVV), the Austrian Party for Freedom (FPÖ), the Norwegian Progress Party (FrP) and the German Alternative for Germany (AfD) whose populist-nationalist platforms have allowed them to mobilise voters, significantly increasing support in domestic electoral arenas. In 2017 these parties performed well, often occupying first, second or third place and in some cases joining governing coalitions (see figure 1). This trend was continued in 2018. During the March 2018 Italian elections, the Lega Nord (LN) occupied third place with $17.69 \%$ of the votes cast and subsequently formed a populist coalition government with the Five Start Movement (M5S). This phenomenon is often understood as the product of a 'cultural backlash' caused by immigration within the context of a new transnational cleavage (Inglehart and Norris 2016). The argument is that within the context of this cleavage, value orientations have become the key drivers of voting behavior, pitting those with universalist beliefs against those who reject multiculturalism and seek to preserve the established value consensus and traditional ways of life.

---Figure 1 about here---

This article contests the view that the 'new nationalism' is a linear, i.e. constantly and consistently increasing over time, novel and uniform phenomenon best understood as a cultural backlash. It argues that while the rhetoric of these parties is indeed centred on nationalism, the drivers of support are neither new nor necessarily nationalism - related. Specifically, using data from the $7^{\text {th }}$ (2014) wave of the European Social Survey (ESS) and the 2017 Comparative Manifestos Project (CMP/MARPOR) dataset, our argument is threefold: (1) it is important to conceptually distinguish between populism and nationalism. The conceptual decoupling of these two terms suggests that the label 'far right' is more analytically useful than 'right-wing populism' because it accounts better for the diversity between parties included in this category, while at the same time it identifies the common denominator that makes them comparable: rather than populism, this is nationalism. This allows us to draw meaningful conclusions about the extent to which this phenomenon is comparable across cases. (2) 
Voters' economic concerns remain pivotal within the context of the transnational cleavage, which suggests that voting behavior continues to be structured by two dimensions of contestation; (3), the explanatory power of nationalism is in the supply, i.e. the ways in which parties use nationalism strategically in an attempt to broaden their appeal by presenting themselves as legitimate to large sections of the population.

The article proceeds as follows. First, we briefly examine existing literature. Second, we offer a conceptual distinction between populism and nationalism, from which it follows that the term 'far right' is a more appropriate label analytically. Third, we focus on demand. We examine the role of economic insecurity within the context of the new transnational cleavage, and specifically economic concerns over immigration using data from the $7^{\text {th }}$ wave of the European Social Survey (ESS). In this section, we also look at the role of specific labour market policies in mediating the risks and costs of economic insecurity on both labour market insiders and outsiders, hence mediating support for the far right. Fourth, we examine supply and focus on the increasing adoption of far right parties of civic nationalism and their programmatic shift to welfare promoters. Using data from the 2017 CMP Manifesto/ MARPOR dataset, we examine overall party positions on nationalism, and specifically positions on welfare, planned economy and the market. The final section concludes with our contribution and recommendations for future research.

\section{The 'new nationalism': populism, immigration and the cultural backlash}

How may we define the 'new nationalism', and what are the causes behind this phenomenon? As noted above, the 'new nationalism' is a term used to describe the rise of parties that share a common emphasis on national sovereignty, strict positions on immigration, the 'national preference', scepticism of supra-national institutions and often anti-elitism. The phenomenon is understood as somewhat uniform emphasising the similarities between such parties across Europe and the US.

The key to the 'new nationalism' phenomenon is the merger of populism and nationalism. Both concepts draw on antagonistic societal relationships. Whether a thin ideology, communication style or strategic tool (see e.g. Mudde and Kaltwasser 2018; Gidron and Bonikowski; Bonikowski et al 2019), populism draws on the antagonistic relationship between 'us' the pure people and 'them' the corrupt elites (Mudde, 2004). It posits that decisions made in society are both legitimate and morally superior only when they are made from below (Riker 1982)- in other words, only when they reflect the general will of the people (Mudde, 2004). For this reason, populism is often described as a form of 'democratic illiberalism' (Pappas, 2016). It is democratic because it draws on the popular will, but it is illiberal in that it is critical of intermediary democratic institutions and seeks to bypass institutional checks and balances such as the Rule of Law and parliamentary scrutiny (Freeden 2017; Bonikowski et al 2019).

Nationalism draws on the antagonistic relationship between the in-group and the out-group (Bonikowski et al 2019). Also often described as a 'thin ideology' 
(Freeden 1998; Halikiopoulou et al 2012; Hall 2011), nationalism seeks the attainment and preservation of the unity, autonomy and identity of the nation (Breuilly, 2005). It thus focuses on national homogeneity and sovereignty and is by definition exclusionary of those who do not belong to the in-group. The 'thin' nature of nationalism is attributed to the fact that, while it may offer systematic answers to national questions, it is unable to offer systematic answers to key domestic social questions (Freeden 1998; Halikiopoulou et al 2012). This explains its chameleon-like ability to attach itself to other ideologies. This Janusfaced quality (Nairn 1975) of nationalism is the basis of the ethnic-civic distinction in the literature: ethnic nationalism on the one hand is exclusive and organic, defined by common descent, native culture and other ascriptive and immutable criteria of national belonging; civic nationalism on the other hand is more inclusive and voluntary emphasizing legal, political and ideological criteria of national belonging (Smith 1991; Zimmer 2003).

Parties that combine nationalist with populist claims make their quest for national sovereignty on the basis of the 'will of the people', the 'people' being the 'pure people' defined in terms of a 'narrow ethnic understanding' of the nation, i.e. nativism (Mudde and Kaltwasser 2018), struggling against a 'corrupt elite' (Mudde 2004). Scholars therefore increasingly prefer the term 'right-wing populism' or 'populist radical right' (e.g see Muis and Immerzeel, 2017; Rooduijn, 2017) to describe these parties which they often associate with ethnic nationalism or nativism (Mudde and Kaltwasser 2018). Research has also focused on the civic elements of nationalism, which are increasingly prioritised in the programmatic agendas of far right parties (Halikiopoulou et al 2013).

In terms of the causes behind this phenomenon, existing literature tends to agree that the increasing electoral success of these parties is linked to voters' concerns over immigration (Golder 2003; Rydgren 2008; Ivarsflaten 2008; Arzheimer 2009; Hainmueller and Hopkins 2014; Rooduijn et al 2017). The immigration issue is especially relevant within the context of an emerging transnational cleavage, which divides voters with cosmopolitan values who support multiculturalism, and those with nationalist values who reject it (Hooghe and Marks 2017). This cleavage is the result of rapid and profound value change in post-industrial societies (Inglehart and Norris 2016) entailing that material factors are less important drivers of voting behaviour than value orientations. Given that values are pivotal within the context of this cleavage, research tends to emphasize the importance of the cultural dimension of competition with immigrants in driving far right party success. What drives voters of these parties is the cultural threat posed by immigration, or in other words, the fear that immigrants challenge the established value consensus by eroding cultural values and traditional ways of life. This is known as 'the cultural grievance thesis' (Golder 2016), according to which far right party support may be best understood as 'a cultural backlash': i.e. a reaction to value change by those who reject universalistic values (Inglehart and Norris 2016). Right-wing populism, therefore, is best understood as the product of a cultural backlash, driven by those on the wrong end of a new transnational cleavage who feel that cosmopolitan elites have made gains at their expense. The strong predictive 
power of cultural concerns at the individual level is often used as evidence for this thesis (e.g. Lucassen and Lubbers 2012; Golder 2016).

In sum, much of the literature assumes that the 'new nationalism' phenomenon is characterised by parties whose programmatic agendas focus on populism and nationalism. This is a fairly new and uniform phenomenon caused by a cultural backlash against immigration. These assumptions, however, are theoretically and empirically problematic. In short, the problem is this: when attempting to explain a phenomenon, the key is the extent to which we are able to explain how a set of identified factors is the cause of a particular outcome. The first step, however, is to define the outcome itself. Therefore, the proposed causes are linked to a certain definition. Illustrating what is problematic about the definition clarifies why this changes the validity of the proposed causes. In other words, we may suggest that an outcome defined as 'Dependent Variable 1' is caused by a set of causes identified as Independent Variable 1; but when we reconceptualise this as 'Dependent Variable 2' we see that set of causes is actually 'Independent Variable 2'.

Specifically: First, electoral support for these parties has not been constantly and consistently rising over time. Instead, it has been fluctuating since the 1980s in what scholars term different waves of support (De Lange 2007). For example, the FN has peaked previously in the 1990s, the Dutch List Pim Fortuyn (LPF) and PVV in 2002 and 2010 respectively, and the FPÖ in 1999 (Halikiopoulou 2018). Second, there is a degree of heterogeneity between these parties, both in terms of what they emphasise in their programmatic agendas and their internal characteristics. A 'one-size-fits-all' explanation overlooks differences in terms of degree of extremism, the adoption of violence, relationship with fascism, position on social issues and state intervention of the economy as well as voting base. This results in tautological and circular claims: if anything outside the established mainstream parties falls under the definition of right-wing populism, then the success of right-wing populism becomes a self-fulfilling prophecy. We need to therefore specify our dependent variable in order to avoid such circular reasoning.

Third, immigration is not just a cultural issue, but rather a multi-faceted one. Indeed recent research draws a distinction between the different sets of threats posed by immigration, including cultural, economic and related to crime and social unrest (Lucassen and Lubbers 2012; Sniderman et al 2004; Rydgren 2008). Finally, there is no a priori reason to expect that demand necessarily drives supply and not the other way round. Again, there is much research on supply itself and the ability of parties to shape their own electoral fortunes (Mudde 2010; Halikiopoulou 2018). This suggests we need to reconsider our demand and supply-side independent variables.

\section{Argument}

This article proposes an alternative explanation that takes these issues into account. Specifically, to address the points about the novelty and uniformity of right-wing populism and avoid circular reasoning, we suggest that it is important 
to conceptually distinguish between the terms 'populism' and 'nationalism' and adopt the 'far right' terminology instead. Such a conceptual distinction allows us to draw meaningful conclusions about the extent to which this phenomenon is comparable across cases. To address the point about the multi-faceted nature of the immigration issue, we use ESS data to examine both cultural and economic concerns over immigration and the extent to which they drive support for these parties. Our findings suggest that voting behavior remains structured by two dimensions of contestation entailing that voters' economic concerns remain pivotal within the context of the transnational cleavage. In order to address the final point about supply, we use CMP/ MARPOR data to examine the positions of the parties themselves. Here we focus on the explanatory power of nationalism as a supply-side dynamic and argue that parties use civic nationalism in their programmatic agendas strategically in an attempt to broaden their appeal and present themselves as legitimate to large sections of the population.

\section{Specifying the dependent variable: 'right-wing populism' versus 'the far right'}

As noted above, the assumption that the 'new nationalism' is a fairly new and uniform phenomenon is problematic, and the problem stems first from our chosen definition. If parties that we categorize as 'right-wing populist' differ in kind rather than just degree, because for example they have different ideological backgrounds and are elected on different platforms (Halikiopoulou 2018), then their rise cannot be traceable to a single cause (Pappas, 2016). Before identifying trends and patterns therefore, it is important that the definition of the dependent variable ensures comparability. The 'right-wing populist' category is problematic in this this respect for two reasons. First, because adopting this definition entails conflating populism and nationalism (see also Mudde and Rovira Kaltwasser 2018; Bonikowski et al 2019); and second because this conceptual conflation results in circular reasoning.

Both populism and nationalism make claims about the collective and feed off conflict lines, pitting one societal group against another. But their similarities end there. While populism pits the people against the elites, nationalism pits the in-group against the out-group. This entails that these two concepts are distinct and should be treated as analytically different. Conflating the two ((Brubaker 2017; Bonikowski 2017; Bonikowski et al 2019) results in a discrepancy between terminology and identification- i.e. the identification of a party as populist, not on the basis of its populist attributes but on the basis of its nationalist attributes.

Beyond nationalism, populism is also conflated with other attributes such as extremism and radicalism, entailing that the 'right-wing populist' category is too broad to be analytically useful. In other words, while nationalists can also be populists and the other way round, it is analytically problematic to identify a populist on the basis of their nationalist attributes and vice versa. Grouping any party that has either nationalist, or extreme, or radical characteristics in the populist category because of these attributes, means that almost any party can be populist. But this begs the question: if populism explains everything, is it then 
not just a tautology? In other words, what is the added value of the term 'populism' when we already know a party because of its nationalist or other attributes? Is populism not superfluous to the 'far right' or 'radical right' category?

Figure 2 illustrates this schematically. Specifically, we identify three criteria based on three different dimensions, for labelling-and distinguishing betweenparties: (1) the extent to which the party invokes the people- this is the 'people versus the elites' dimension; (2) the extent to which the party invokes the nation- this is 'the in-group versus the out-group' dimension; and (3) the ways in which the exclusion of the out-group is justified- this is the 'ethnic versus civic' dimension. Based on these three criteria, Figure 2 identifies six different party outcomes that are conceptually possible. First, a party that is neither populist, nor nationalist; second, a party that is not populist, but is nationalist and adopts a civic narrative; third, a party that is not populist, but is nationalist and adopts an ethnic narrative; Fourth a party that is both populist and nationalist and adopts a civic narrative; fifth a party that is both populist and nationalist and adopts an ethnic narrative; an sixth a party that is populist but not nationalist. Making this conceptual distinction allows us to differentiate between the factors that may account for the electoral success of these parties.

---Figure 2 about here---

In sum, the conceptual conflation between populism and nationalism entails that we are unable to establish whether it is the populist or the nationalist element that explain party success. We suggest an alternative definition, which allows us to disentangle the two. On the basis of this definition we carry out our supplyside analysis below and show it is a shift in the nationalist, and not the populist, content that explains success.

What is needed is a term that ensures comparability by both accounting for the different variants, and at the same time identifying the common denominator that makes them comparable. This article argues that the term 'far right' is more useful analytically because it best meets these criteria. It should be noted that regardless of terminology, this is a diverse party family, and no classification is without problems (see e.g. Ennser 2012) whether one chooses 'radical right' (Immerzeel et al 2015), 'far right' (Halikiopoulou and Vlandas 2016), 'extreme right' (Arzheimer 2009) or 'populist radical right' (Mudde and Kaltwasser 2018; Muis and Immerzeel 2017; Rooduijn 2017). Nonetheless, the term 'far right' is more appropriate because it better accounts for the diversity between parties included in this category, while at the same time it identifies the common denominator that makes them comparable: rather than populism, this is nationalism. This would include all parties depicted in Figure 2 that are nationalist- including those who adopts both ethnic and civic narrativesregardless of whether they are populist or not. In other words, while populism may or may not be one attribute of these parties, the defining feature, and common across their programmatic agendas, is nationalism. 
The 'far right' umbrella term allows us on the one hand to identify the similarities between parties and groups that propose nationalist solutions to a broad range of socio-economic societal problems (Vasilopoulou and Halikiopoulou 2015; Ellinas 2011), therefore facilitating comparison. Such parties justify a broad range of policy positions on the basis of nationalism. To clarify: the point here is not simply that they are all, to a degree, nationalist. The point is that they use nationalism to justify their positions on all socio-economic issues (Vasilopoulou and Halikiopoulou 2015). In other words, the in-group/ out-group distinction is key to their programmatic agendas. The pursuit of the 'national preference' is the common denominator underlying all their policy solutions, ranging from the economy, social services, welfare provision and foreign policy. This need not solely be ethnic nationalism.

On the other hand, this term allows us to distinguish between different variants, which range from extreme to radical, facilitating the identification of typologies and patterns within this broader category. We might distinguish between two types of groups: first, extreme right variants. This category includes both vigilante groups and political parties that are often openly racist, have clear ties to fascism and also employ violence and aggressive tactics. These groups may operate either outside or within the realm of electoral politics, or both. They tend to oppose procedural democracy. The second type refers to the radical right variants, which tend to be the most widespread and electorally successful in Europe. These parties accept procedural democracy, they have distanced themselves from fascism and they themselves oppose the far right label. Examples abound: the French FN (now Rassemblement National), the Dutch PVV, the Swiss People's Party (SVP), the Sweden Democrats (SD), the AfD and the Danish People's Party (DF) among others. These parties also use nationalism to justify all their policy positions. Instead of the ethnic nationalist narrative, however, adopted by extreme right parties, which focuses on blood, creed and common descent, radical right parties utilise a civic nationalist narrative to promote their anti-immigrant agendas (Halikiopoulou et al 2013). In other words, this term allows us to compare parties and groups without treating them as one-size-fits-all. Our reconceptualization of the dependent variable as consisting of far right parties that may utilize both ethnic and civic forms of nationalism allows us to make this argument, and goes beyond literature that posits that far right parties adopt a narrow ethnic understanding of who belongs to the people, i.e. 'nativism' (Mudde and Kaltwasser 2018).

In sum this section has argued that in order to make meaningful conclusions about the 'new nationalism' phenomenon, we first need to specify the dependent variable. The term 'right-wing populism' is problematic because it is too broad and conflates populism with nationalism and other party characteristics. As such we propose the adoption of the term 'far right' in order to define parties whose common denominator is nationalism as justification of all policy positions, but differ in terms of their degree of extremism and their adoption of an ethnic or civic nationalism. The rest of this article proceeds to examine the demand and supply-side dynamics behind the rise of these parties. 


\section{The demand-side: Immigration and economic insecurity in the context of the transnational cleavage}

In this section we address the point about the multi-faceted nature of the immigration issue. Much of the 'cultural backlash' thesis is premised on the finding that immigration is a key driver of far right party support. However, it is not clear that indicators such as anti-immigration attitudes are necessarily always cultural. A large body of literature suggests that while cultural concerns over immigration are indeed a stronger predictor, perceptions on immigration are associated with both cultural and economic threats (see e.g. Sniderman et al 2004; Lucassen and Lubbers 2012; Rydgren 2008). Even within the new transnational cleavage there are therefore good reasons, both theoretically and empirically, to continue to focus on the impact of material factors and selfinterest on policy preferences and party choice (Marx 2014, Hausermann and Schwander 2009, Rueda 2007; Rehm 2016; Vlandas 2013) and perceptions of labour market competition with immigrants (Mayda 2006). This suggests that immigration attitudes are not necessarily value- based and that the culture versus economy distinction may be a false dichotomy (Burns and Gimpel 2000; Gidron and Hall 2017). As a result, divisions between various social groups and segments of the electorate with distinct economic endowments and facing different labour market risks likely remain key politically, even in the context of a relative decline in traditional cleavages. As Kriesis (1998: 165) notes, the new transnational cleavage are 'strongly shaped by the political legacy of traditional cleavages' (Kriesi 1998: 165).

In this section we use data from the seventh round (2014) of the European Social Survey (ESS) which has been used extensively in previous research on both immigration attitudes and far right support (See e.g. Citrin and Sides 2008; Ivarsflaten 2008; Rydgren 2008; Lucassen and Lubbers 2012; Inglehart and Norris 2016). Specifically, we examine economic and cultural individual concerns about immigration and the extent to which they shape antiimmigration attitudes and far right party support, using a specially designed survey experiment from the ESS immigration module. Following previous work (see e.g. Lucassen and Lubbers 2012) we restrict our sample to the 14 countries $^{1}$ in which there is demand for far right parties and using the far right classification described above we examine a total of 18 parties $^{2}$.

\footnotetext{
${ }^{1}$ Austria, Belgium, Denmark, Finland, France, Germany, Hungary, Lithuania, Netherlands, Poland, Portugal, Sweden, Switzerland, United Kingdom.

2 Austrian Freedom Party (FPÖ), Alliance for the Future of Austria (BZÖ), Flemish Interest (VB), Front National Belge (FNb), Danish People's Party (DF), True Finns (PS), Front National (FN), National Democratic Party of Germany (NPD), Alternative for Germany (AfD), Order and Justice Party (TT), Party 'Young Lithuania' (JL), Movement for a better Hungary (Jobbik), Party for Freedom (PVV), Congress of the New Right (KPN), Law and Justice (Pis), Swiss People's Party (SVP), Sweden Democrats (SD) and the United Kingdom Independence Party (UKIP).
} 
Our first step is to examine whether economic or cultural concerns matter more in explaining anti-immigration attitudes. We use an experimental design, which is made possible by the survey experiment carried out in this wave of the ESS. Specifically, the survey asked respondents whether they thought there should be 'many' immigrants coming to live in their country (1), 'some' (2), 'a few' (3), or 'none' (4). Different respondents were randomly exposed to different statements about the origin and economic status of immigrants, as shown in Table 1. Two treatments are created to capture the four cells: a 'professional treatment' is equal 1 to if the question refers to professionals and 0 otherwise, while a 'Europe treatment' is equal to 1 if the question refers to a European country of origin and 0 otherwise. We use this experiment in order to assess whether economic (as captured by the 'professional treatment') or cultural (as captured by the 'Europe treatment') concerns are most important in determining individuals' antiimmigration attitudes.

---Table 1 about here---

Before looking at the effects of the treatments, we first run an ordinal logistic regression analysis on a series of relevant controls without the treatments. Specifically, we include controls for the age, education (in years), and gender of the respondent, as well as for the level and source of their income, and their occupation (managers, professionals, technicians, clerical, service, agriculture, craft, operators, elementary), which differ both in terms of the level and specificity of the skills involved. The results reveal that younger, more educated, high-income (not significant) male respondents are less likely to oppose immigration (not shown in the article but available from the authors). Craft workers, operators and those working in agriculture are most opposed to immigration, while professionals are most favourable. This is in line with literature that expects those in low-skilled occupations to be more likely to hold stronger anti-immigrant views (Mayda 2006; Dancygier and Donnelly 2013).

We proceed to include both our treatments in the model and no controls: this suggests that the professional treatment reduces the probability of being against immigration to a larger extent (column 1, Table 2). Next, we include all our controls and the result remains the same (column 2, Table 2). One way to visualise the results is to calculate the predicted probabilities for all four combinations of the two treatments, which is shown in Figure 3. Respondents are most likely to choose (1) 'allow many' (top left quadrant) when asked about professionals from Europe. Asking them about professionals from outside Europe reduces this probability but not as much as asking them about unskilled labourers (i.e. removing professional treatment) from inside Europe. Conversely, respondents are most likely to choose 'allow none' if asked about unskilled labourers from outside Europe and adding the professional treatment has a larger negative effect on this probability than adding the Europe treatment (bottom right quadrant of figure 3).

One assumption of the ordinal logistic regression is that there is a similar proportionality between each point/value of the ordinal scale - or in other words that it makes sense to treat each response as part of an ordinal scale 
rather than as distinct categories with no systematic ordering. We can test whether this assumption is correct by carrying out a brant test, which yields a significant test statistic (confirmed by likelihood-ratio test of proportionality of odds). This provides evidence that the parallel regression assumption has been violated so as robustness checks we also run a binary logistic regression where there are only two values (bypassing the question of proportionality between different points of the ordinal scale) and a multinomial logistic regression which treats each point of the ordinal scale as separate answers. In columns 3 to 5 we rerun our analysis with a multinomial logistic regression: this confirms that the professional treatment has a larger effect (and the coefficient for the Europe treatment is not significant when focusing on the 'allow many' outcome). In column 6 , we run a binary logistic regression where 1 is 'allow none' and 0 combines the other three responses and the results are similar. In column 7, we include country fixed effects and our main finding remains.

---Table 2 about here---

---Figure 3 about here---

We now turn our attention to the impact of immigration concerns on far right party choice. Because the experiment was designed to assess impact of immigration question on immigration concerns, we cannot use responses to this question to assess impact of immigration concerns on far right party support. Instead we rely on two other questions included in this ESS wave. Specifically, the ESS includes questions that ask respondents whether they think their country's cultural and economic life is undermined (0) or enriched (10) by immigrants (henceforth 'cultural concerns about immigration' and 'economic concerns about immigration'). We run a binary logistic regression with robust standard errors clustered by country to test the impact of these two types of concerns over immigration on far right party support. Figure 4 shows the predicted probabilities of voting for the far right for different values of economic and cultural immigration attitudes (the regression controls of age, gender, education, income, source of income - e.g. wage, self-employment, pension, unemployment benefits - and occupation). Respondents with very positive views of the cultural impact of immigration have consistently low probabilities of voting for the far right regardless of their beliefs about its economic impact. By contrast, among those with very negative views of immigration's impact on culture, their views of immigration's impact on the economy matters, with the probability varying from a high of above $30 \%$ to a low below $15 \%$. These results indicate that overall cultural concerns over immigration are a stronger predictor of far right party support, but that economic concerns also matter.

---Figure 4 about here---

Finally, we cross-tabulate the far right vote against each type of immigration concern in order to show that voters who are concerned with the impact of immigration on the economy are more important to the far right in numerical terms than those concerned with its impact on culture. We show the results in the left panel of Table 3. Among those respondents who are concerned with the impact of immigration on the economy, 19\% voted for the far right, compared 
with nearly $23 \%$ for those with concerns about immigration's impact on culture. This is consistent with the earlier findings that those with cultural concerns are more likely to vote for the far right so the cultural concerns have stronger predictive power. However, if we turn our attention to the absolute numbers of voters with different types of immigration concerns, the picture changes. Indeed, 901 people with economic concerns voted for the far right while 3,835 did not. By contrast, among those with cultural concerns, 799 voted for far right while 2,714 did not. Even though a higher percentage of people with cultural concerns voted for the far right, in absolute terms those with economic concerns were more numerous. This suggests that far right parties need to mobilise both groups, i.e. voters concerned with the cultural as well as the economic impact of immigration, and that the more numerous latter group is pivotal in allowing the far right to extend its support beyond its secure voting base.

\section{---Table 3 about here---}

\section{Labour market policies as mediating factors}

Our analysis above indicates that economic insecurity still plays an important role, even within the context of the transnational cleavage, in driving far right party support. Further, we contend that social policies mediate the impact of economic insecurity on far right party support (Halikiopoulou and Vlandas 2016; Vlandas and Halikiopoulou 2018). Deteriorating economic conditions may have a negative impact on the expectations and/ or the socio-economic status of both labour market outsiders (i.e. the unemployed and those in precarious contracts) and insiders (i.e. those in permanent employment). In class terms, this points to the crucial importance of unemployment and labour market institutions not just for the working class but also for broad segments of the middle classes. This is consistent with recent research, which finds that voting for populist parties can be explained through a relative deprivation mechanism (See e.g. Rooduijn and Burgoon 2017; Mudde and Rovira Kaltwasser 2018).

In a previous contribution, we theorise and test why and how unemployment is associated with higher far right party support only when certain labour market institutions are absent. Theoretically, we argue that unemployment may increase insecurity through two distinct channels: (1) it imposes costs on the unemployed but these costs are a function of unemployment benefit replacement rates (the extent to which benefits replace previous salary) and it increases the risks for those that are employed but this risk depends on the degree of employment protection legislation (EPL - the ease with which employers may dismiss workers on permanent contracts). Empirically, we find that indeed unemployment is not on average associated with the cross-national variation in far right party support in the last three European Parliament elections. The association is only positive and statistically significant when certain labour market institutions are in place (Halikiopoulou and Vlandas 2016).

Specifically, we find that "unemployment does have a positive association with far-right party support in countries where unemployment benefits replace strictly less than 50 per cent of previous income while working; beyond this 
level, unemployment is no longer significantly different from 0 (ibid: 649). Similarly, our results further show that "unemployment does have a positive association with far-right support in countries where the OECD EPL index is lower than slightly above 2; beyond this level, unemployment is no longer significantly different from 0" (ibid: 650). Finally, unemployment benefits, but not EPL, also have a statistically significant and independent negative effect on far right party support: more generous benefits reduce overall support of far right parties, regardless of unemployment level (ibid, table 1, page 647).

In more recent work, we replicate these findings using data on national elections in 14 Western and 10 Eastern European countries between 1991 and 2013. We find that unemployment only leads to higher far-right support when unemployment benefits replacement rates are low. The results with regards to the mediating effect of EPL are more complex as the latter only mediates the impact of unemployment when we take into account the share of foreign - born population in the country (Vlandas and Halikiopoulou 2018).

\section{The supply-side: civic nationalism and social welfare}

So far we have argued that the insecurities that drive far right party support are not necessarily nationalism- related. While cultural insecurities are indeed important, economic insecurities also matter within the context of the new transnational cleavage. Parties need to mobilise voter groups with both insecurities in order to be electorally successful. In short, citizens' discontent with a series of societal, political and economic issues drives their voting behavior. This is not new. Such discontent has been associated with the rise of extremism, both left and right, in the past (see e.g. Arendt 1051; Lipset 1960; Bell 1964). As more recent research has argued demand is often a constant (see e.g. Bonikowski 2017; Halikiopoulou 2018), and national level variables including immigration (Stockemer 2015) and unemployment (Halikiopoulou and Vlandas 2016) do not necessarily correlate with far right party support.

This points to the importance of supply. Research often argues that demand-side explanations should be complemented by analyses of the supply-side, for example the role of the media (Murphy and Devine 2018), the electoral system and dynamics of party competition (Carter 2002; Mudde 2007), as well as the parties themselves and their ability to capitalize on voter insecurities and shape their own electoral fortunes (Koopmans and Statham 1999; Mudde 2010; Halikiopoulou et al 2013; Vasilopoulou and Halikiopoulou 2015). Drawing on this literature, we argue that the importance of nationalism lies in the supplyside. Specifically, along the lines of Vasilopoulou and Halikiopoulou (2015) we argue that what makes far right parties successful is their ability to offer nationalist solutions to all types of insecurities that drive voting behaviour; and along the lines of Halikiopoulou et al (2013) we argue that these parties capitalize on multiple insecurities by using a civic nationalist rhetoric, i.e. one that excludes on the basis of ideological rather than biological criteria of national belonging. This allows them to portray their solutions to voters' insecurities as legitimate and therefore increase their appeal among broader segments of the 
population, including voters who are uncomfortable to opt for an explicitly racist party. The increasing appeal of far right parties to the middle classes is consistent with our argument: these parties have been able to extend their voting base beyond the classic far-right constituency, to attract those suffering from relative deprivation within a context of favorable conditions at the aggregate level (Rooduijn and Burgoon 2017), more women (Mayer 2015) and younger voters (Stockemer and Amengay, 2015).

The majority of successful European far right parties, including for example the FN, AfD and the PVV share this 'civic nationalist normalization' strategy. Notable exceptions include certain far right parties in Southern Europe- for example the Greek Golden Dawn (Vasilopoulou and Halikiopoulou 2015) and Eastern Europefor example the Hungarian Jobbik and the Bulgarian Ataka (Pirro 2014) which have attracted voters despite their ethnic nationalism, endorsement of violent practices and links to fascist principles. These parties differ from their Western European counterparts for a number of reasons including the different types of nationalism that are dominant in these countries, different historical legacies, and different political cultures.

The 'civic nationalist normalization' strategy adopted by the majority of successful Western European far right parties has two features. First, it presents culture as a value issue. Justification of exclusion is made on purported threats posed by those who do not share 'our' liberal democratic values. This strengthens the ability of these parties to mobilise on issues such as terrorism by linking their narratives to immigration, democracy and security. The justification is that certain cultures and religions are intolerant and inherently antithetical to democratic values. This explains why these parties are increasingly targeting Muslims as the hostile 'others' who should be excluded from 'our' nation. Attempting to refrain from ascriptive criteria of exclusion, these parties argue instead that Muslims pose a danger to the liberal democratic consensus that characterises Western European societies. Invoking a form of a 'clash of civilisation' thesis they argue that it is the ideology of Islam that makes Muslims intolerant of liberal democratic values. The AfD poster campaign during the 2017 German election is a good case in hand. The party's communication strategy was based on the choice of a series of images that depicted Islam as a threat to German values. Examples include a picture of a small pig under the caption 'Islam does not fit our kitchen' (der islam passt nicht zu unserer küche'); an image of two white German girls in bikinis under the caption 'Burkas? We prefer bikinis' ('Burkas? wir steh'n auf bikinis'); and a picture of three white German girls in traditional dress, drinking a glass of wine, under the caption 'Burka? I prefer Burgundy' ('Burka? ich steh mehr auf burgunder') (AfD 2017).

The second feature is a focus on social welfare (Afonso and Renwald 2017; Röth et al 2018; Afonso and Papadopoulos 2015), which draws on economic nationalism as an important aspect of the social contract between state and citizens (Halikiopoulou and Vasilopoulou 2018). As part of their civic adoption of a civic nationalist narrative, a number of these parties has shifted from the neoliberal economic 'winning formula' (Kitchelt with McGann 1995) of past years to adopt a new, more economically centrist, position (Ivaldi 2015; De Lange 2007). 
This move from market liberal to welfare chauvinist policy proposals has coincided with moves by some social democratic parties towards welfare state policies that de-prioritise interest of labour market outsiders (Rueda 2007).

Using data from the 2017 CMP Manifesto/ MARPOR dataset (Volkens et al 2017) we illustrate this point by examining party positions on welfare, economic planning and market liberalisation. We focus on two specific parties, i.e. the FN and the FPÖ, which both enjoyed an increase in their electoral support in 2017. These parties compete within very different political systems, in countries with different historical legacies. They are, however, relatively old parties allowing us to make observations with regards to their programmatic agendas comparatively across time. Figures 5 and 6 illustrate these parties' positions on the three issues mentioned above using three indexes. First, the 'welfare index' captures equality (i.e. positive mentions on social justice and the need for fair treatment of all people) and welfare state expansion (i.e. favourable mentions of need to introduce, maintain or expand any public social service or social security scheme). Second, the 'planned economic index' captures market regulation (i.e. support for policies designed to create a fair and open economic market), economic planning (i.e. favourable mentions of long-standing economic planning by the government) and support for direct government control of the economy. Finally, 'the market economic index' captures support for the free market and free market capitalism as well as economic orthodoxy (i.e. the need for economically healthy government policy making). (See et al (2017) for more details on party manifesto data). As figure 5 illustrates, the FN has increasingly supported welfare state expansion and direct government control of the economy, while reducing its support for market liberalism overtime. The same applies for the FPÖ, although there are more fluctuations in this case with regards to its support for economic planning (See figure 6).

This allows them to mobilize the economically insecure by linking immigration, unemployment and (a purported) welfare scarcity. They can increase their appeal to a broader group of voters by simultaneously distancing themselves from fascism and appearing to address both cultural (through the values narrative) and economic (through their welfare chauvinist) insecurities.

---Figure 5 about here---

---Figure 6 about here---

\section{Conclusion}

This article has focused on the 'new nationalism', and specifically on the rise of parties that focus on delivering politics back to the people, restoring national sovereignty and limiting immigration. We have contested the view that this phenomenon is a new, linear, uniform and solely demand-side phenomenon caused primarily by a cultural backlash against increasing immigration within the context of an emerging post-materialist cleavage. 
In sum, this article has made three points: First, the term 'right-wing populism' often conflates populism and nationalism resulting in analytical confusion and circular reasoning. We suggested that the term 'far right' offers a more appropriate description of these parties. Second we discussed the causes of far right party support, focusing on both demand and supply-side dynamics. In terms of demand, we used data from the $7^{\text {th }}$ wave of the European Social Survey (ESS) to show that economic insecurity, in the form of concerns of the impact of immigration on the economy, remains important within the context of the transnational cleavage. We extended our argument by discussing literature that focuses on the extent to which labour market institutions mediate economic insecurity thereby limiting far right party support. In terms of supply, we used data from CMP/ MARPOR 2017 dataset to show that nationalism is an important supply-side explanatory factor. Contrary to literature, which argues that far right parties adopt a primarily ethnic form of nationalism, and in line with Halikiopoulou et al. (2013) we argued that successful European far right parties increasingly adopt a civic narrative. This narrative is characterized by two features: value-based exclusion and welfare chauvinism.

Our article contributes to the study of the 'new nationalism' by bridging three literatures, i.e. nationalism, far right voting and political economy, which remain disconnected. While a large body of literature agrees that nationalism is key to the programmatic agenda of far right parties, the relationship between the two remains under-theorised and the literature rarely goes beyond including it in the definition of the party family. On the contrary, the assumption is that nationalism is a demand-side dynamic, and factors such as immigration tend to be treated as cultural, thus often overlooking their economic dimension. We have shown the importance of nationalism as a central feature of the far right party family; and by conceptually disentangling populism and nationalism we have shown why the latter has greater explanatory power than the former. We have also illustrated, both theoretically and empirically, that this need not necessarily be a narrow ethnic type of nationalism, as much of the literature expects; but rather that the adoption of a civic form of nationalism is the strategic choice of a number of far right parties that are faring well electorally across Europe. Finally in terms of demand for the far right, by focusing on the numerical importance of voters concerned with the impact of immigration on the economy, we have shown the importance of economic insecurity as a driver of far right party support within the context of the new transnational cleavage.

Future research could focus on three related areas. First, studies should focus on the links between demand and supply-side dynamics. As noted above, the two tend to be treated separately, with research focusing on either societal triggers such as the influx of immigrants, globalisation and value change; or the parties themselves, their discourse and rhetorical style. Second, more work is needed examining the different types of nationalism adopted by different far right parties, depending on context and circumstance. The identification of different patterns through comparative work is much needed, particularly comparing far right parties in Eastern, Southern and Northwest Europe, given that the nationalist narratives they adopt differ fundamentally. Third, more work should be carried out on the economic dimension of nationalism, which remains under- 
theorised in the party politics and voting behaviour literatures that tend to treat nationalism as a cultural factor. New work should focus both on economic nationalism as a demand-side factor, i.e. a driver of anti-immigrant attitudes and far right party support; and as a supply-side factor, examining the ability of these parties to mobilise through narratives that emphasise various dimensions of economic nationalism, both in Northwest Europe, where these narratives stress the need to secure the in-group from debtor country immigrants who seek access to jobs and welfare; and in Southern Europe where the economic crisis has contributed to a scarcity of the collective goods of the state.

\section{References}

Afonso, A. and Rennwald, L. (2017), 'Social class and the changing welfare state agenda of Populist Radical Right Parties in Europe', in P. Manow and B. Palier (eds), Electoral Realignments and Welfare State Transformations in Europe, Oxford: Oxford University Press.

Afonso, A. \& Y. Papadopoulos (2015) "How the Populist Radical Right Transformed Swiss Welfare Politics: From Compromises to Polarization", Swiss Political Science Review

AfD (2017) https://www.afd.de [accessed December 2017).

Arendt, H. (1951) The origins of totalitarianism. Cleveland: Meridian Books

Arzheimer, K. (2009) 'Contextual Factors and the Extreme Right Vote in Western Europe, 1980-2002'. American Journal of Political Science, Vol. 53, No. 2, pp. 259-75.

Bell, D. (1964) 'The Dispossessed', in Bell, D. (ed.) The Radical Right. Garden City, NY: Anchor, pp. 1-45.

Bonikowski, B. (2017). "Ethno-Nationalist Populism and the Mobilization of Collective Resentment." The British Journal of Sociology 68 (S1): 181-213.

Bonikowski, B., Halikiopoulou, D., Kaufmann, E. and Rooduijn, M. (2019 forthcoming). Nations and Nationalism Exchange: Nationalism and Populism., Nations and Nationalism 19:1

Breuilly, J. (2005) 'Dating the Nation: How Old is an Old Nation?' In Ichijo, A. and Uzelac, G. (eds) When is the Nation? Towards an Understanding of Theories of Nationalism (London: Routledge), pp. 15-39.

Brubaker, R. (2017). Why Populism? Theory and Society, 46: 357.

Burns, Peter and James G. Gimpel. 2000. "Economic Insecurity, Prejudicial Stereotypes, and Public Opinion on Immigration Policy.” Political Science Quarterly, 115: 2, pp. 201-225 
Carter, E. (2002), 'Proportional Representation and the Fortunes of Right-wing Extremist Parties', West European Politics, 25(3): 125-46.

Citrin, Jack and John Sides. 2008. "Immigration and the Imagined Community in Europe and the United States." Political Studies, 56, pp. 33-56 doi:

10.1111/j.1467-9248.2007.00716.x

Dancygier, Rafaela M. and Michael J. Donnelly. 2013. "Sectoral Economies, Economic Contexts, and Attitudes toward Immigration." The Journal of Politics, 75: 1 , pp. $17-35$

De Lange, S. L. (2007) A new winning formula? The programmatic appeal of the radical right. Party Politics 13:4, pp. 411-435

Ellinas A (2011) The media and the far right in Western Europe: Playing the Nationalist Card. Cambridge: Cambridge University Press.

Ennser L (2012) The homogeneity of West European party families: The radical right in comparative perspective. Party Politics 18: 151.

Freeden, M. (1998). Is nationalism a distinct ideology? Political Studies 46: 748765.

Freeden, M. (2017) After the Brexit referendum: revisiting populism as an ideology, Journal of Political Ideologies, 22:1, pp.1-11

Gidron, N. and P. Hall (2017) The politics of social status: Economic and cultural roots of the populist right, The British journal of sociology, 57-84

Golder, Matt. 2003. "Explaining Variation In The Success Of Extreme Right Parties In Western Europe." Comparative Political Studies 2003; 36; 432 DOI: $10.1177 / 0010414003251176$

Golder, Matt. 2016. "Far right parties in Europe." Annual Review of Political Science 19: 477-97.

Hainmueller, Jens and Daniel J. Hopkins. 2014. "Public attitudes towards immigration, Annual Review of Political Science." 17:225-249

Halikiopoulou, D. , Nanou, K. And Vasilopoulou, S. (2012), The paradox of nationalism: The common denominator of radical right and radical left euroscepticism. European Journal of Political Research, 51: 504-539.

doi:10.1111/j.1475-6765.2011.02050.x

Halikiopoulou, D., Mock, S. and Vasilopoulou, S. (2013) 'The Civic Zeitgeist: Nationalism and Liberal Values in the European Radical Right'. Nations and Nationalism, Vol. 19, No. 1, pp. 107-27. 
Halikiopoulou, D. and Vlandas, T. (2016) 'Risks, Costs and Labour Markets: Explaining Cross-National Patterns of Far-Right Party Success in European Parliament Elections'. JCMS, Vol. 54, No. 3, pp. 636-55.

Halikiopoulou, D., \& Vasilopoulou, S. (2018). Breaching the Social Contract: Crises of Democratic Representation and Patterns of Extreme Right Party Support. Government and Opposition, 53(1), 26-50. doi:10.1017/gov.2015.43

Halikiopoulou, D. (2018) A Right-wing Populist Momentum? A Review of 2017 Elections Across Europe. JCMS: Journal of Common Market Studies, https://doi.org/10.1111/jcms.12769.

Hall, J. (2011). Nationalism might change its character, again. In Halikiopoulou, D. \& Vasilopoulou, S. (eds), Nationalism and globalisation: Conflicting or complementary? London: Routledge.

Häusermann, Silja and Schwander, Hanna. 2009. "Identifying outsiders across countries: similarities and differences in the patterns of dualization." RECWOWE working paper.

Hooghe, Lisbet and Gary Marks. 2017. “Cleavage theory meets Europe's crises: Lipset, Rokkan, and the transnational cleavage." Journal of European Public Policy, DOI: 10.1080/13501763.2017.1310279.

Inglehart, R. and Norris, P. (2016) 'Trump, Brexit, and the Rise of Populism: Economic Have-Nots and Cultural Backlash', Harvard Kennedy School Faculty Research Working Paper Series, No RWP16-026.

Ivarsflaten, Elisabeth. 2008. "What unites right-wing populists in Western Europe? Re- examining grievance mobilization models in seven successful cases." Comparative Political Studies, 41: 3- 23.

Kitschelt, H. with McGann, A. (1995) The Radical Right in Western Europe. A Comparative Analysis. Ann Arbor, MI: University of Michigan Press.

Koopmans, R. and Statham, P. 1999. 'Ethnic and civic conceptions of nationhood and the differential success of the extreme right in Germany and Italy' in M. Giugni et al. (ed.), How Social Movements Matter. Minneapolis, MN: University of Minnesota Press, 225-51.

Kriesi, Hanspeter. (1998). The transformation of cleavage politics: the 1997 Stein Rokkan lecture, European Journal of Political Research, 33, pp. 165-185

Lipset, S.M. (1960), Political Man: The Social Bases of Politics (New York: Doubleday).

Lubbers, Marcel and Marcel Coenders. 2017. "Nationalistic attitudes and voting for the radical right in Europe." European Union Politics, 18: 1, pp. 98 - 118 
Lucassen, Geertje and Marcel Lubbers. 2012. "Who Fears What? Explaining FarRight-Wing Preference in Europe by Distinguishing Perceived Cultural and Economic Ethnic Threats." Comparative Political Studies, 45(5): 547-574.

Marx, Paul. 2014. "Labour Market Risks and Political Preferences: The Case of Temporary Employment." European Journal of Political Research, 53(1): 136159.

Mayda, Anna Maria. 2006. "Who is against immigration? A cross-country investigation of individual attitudes toward immigrants." The Review of Economics and Statistics, 88:3, pp. 510-530

Mayer N (2015) The closing of the radical right gender gap in France? French Politics 13:391-414.

Mudde, C. 2004. 'The Populist Zeitgeist', Government and Opposition, Vol. 39, No. 4, pp. 542- 563 .

Mudde, Cas. 2007. Populist radical right parties in Europe. Cambridge: Cambridge University Press.

Mudde, C. and Rovira Kaltwasser, C. (2018) Studying Populism in Comparative Perspective: Reflections on the Contemporary and Future Research Agenda, Comparative Political Studies, doi.org/10.1177\%2F0010414018789490

Muis, J. and Immerzeel, T. (2017) 'Causes and Consequences of the Rise of Populist Radical Right Parties and Movements in Europe'. Current Sociology, Vol. 65, No. 6, pp. 909-30.

Nairn, T. (1975). The modern Janus. New Left Review 1(94): 3-29.

Pappas, T.S. (2016) 'The Spectre Haunting Europe: Distinguishing Liberal Democracy's Challengers'. Journal of Democracy, Vol. 27, No. 4, pp. 22-36.

Polavieja, Javier. G. 2016. "Labour-market competition, recession and antiimmigrant sentiments in Europe: occupational and environmental drivers of competitive threat." Socio-Economic Review, 14: 3, pp. 395-417 doi: $10.1093 / \mathrm{ser} / \mathrm{mww} 002$

Rehm, Philipp. 2016. Risk Inequality and Welfare States. Cambridge et al.: Cambridge University Press.

Riker, W. (1982) Liberalism against Populism: A confrontation between the theory of democracy and the theory of social choice. Illinois: Waveland Press

Rooduijn, M. (2017) 'What Unites the Voter Bases of Populist Parties? Comparing the Electorates of 15 Populist Parties'. European Political Science Review, pp. 118. 
Röth, L., Afonso, A., \& Spies, D. (2018). The impact of Populist Radical Right Parties on socio-economic policies. European Political Science Review, 10(3), 325-350. doi:10.1017/S1755773917000133

Rueda, David. 2007. Social democracy inside out. Partisanship and labour market policy in industrialised democracies, ed. Oxford University Press (Oxford).

Rydgren, Jens. 2008. "Immigration sceptics, xenophobes or racists? Radical rightwing voting in six West European countries". European Journal of Political Research, 47: 737-765. doi:10.1111/j.1475-6765.2008.00784.x

Smith, A.D. (1991). National Identity. London: Penguin

Sniderman, Paul M., Louk Hagendoorn and Markus Prior. 2004. "Predisposing factors and situational triggers: Exclusionary reactions to immigrant minorities". American Political Science Review, 98, 35-49.

Stockemer, D. (2016) Structural Data on Immigration or Immigration Perceptions? What Accounts for the Electoral Success of the Radical Right in Europe?. JCMS: Journal of Common Market Studies, 54: 999-1016.

doi: $10.1111 /$ jcms.12341.

Stockemer D and Amengay A (2015) The voters of the FN under Jean-Marie Le Pen and Marine Le Pen: Continuity or change? French Politics 13:370-390. doi:10.1057/fp.2015.16

Vlandas, Tim. 2013. "The Politics of Temporary Work Deregulation in Europe: Solving the French Puzzle”, Politics \& Society, 41 (3), 425-60.

Volkens, Andrea, Lehmann, Pola, Matthieß, Theres, Merz, Nicolas, Regel, Sven and Weßels, Bernhard (2017): The Manifesto Project Dataset - Codebook. Manifesto Project (MRG / CMP / MARPOR). Version 2017b. Berlin:

Wissenschaftszentrum Berlin für Sozial- forschung (WZB).

Zimmer, 0. (2003). Boundary mechanisms and symbolic resources: Towards a process-oriented approach to national identity. Nations and Nationalism 9(2): 173-193. 


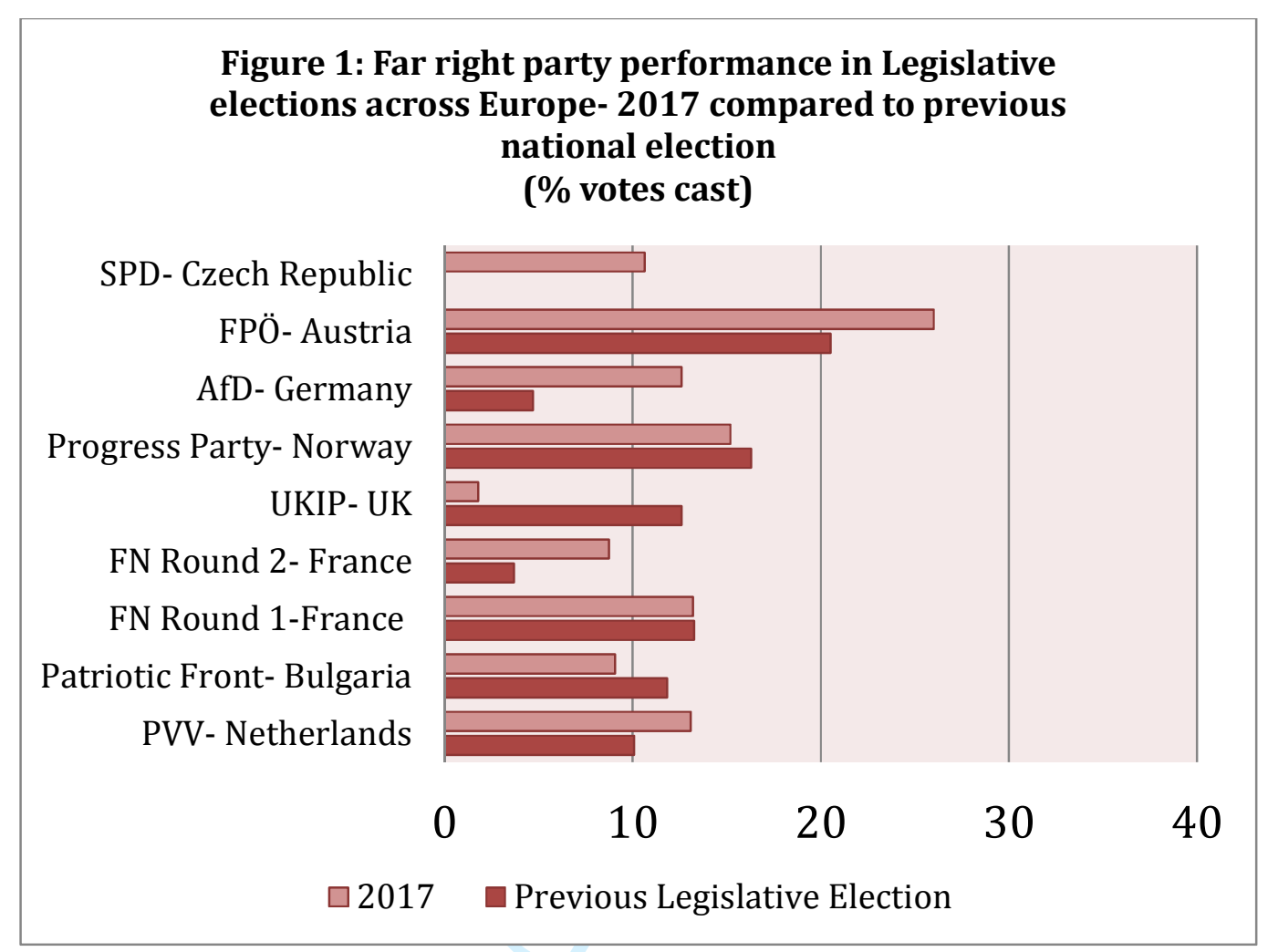


Figure 2: Distinction between populism and the (new) nationalism

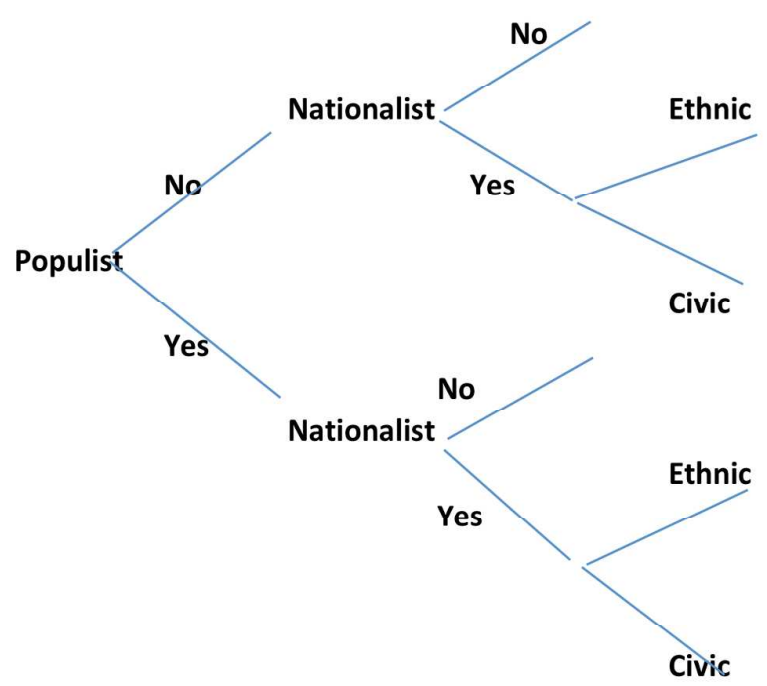


Figure 3: Predicted probabilities using a survey experiment on immigration attitudes
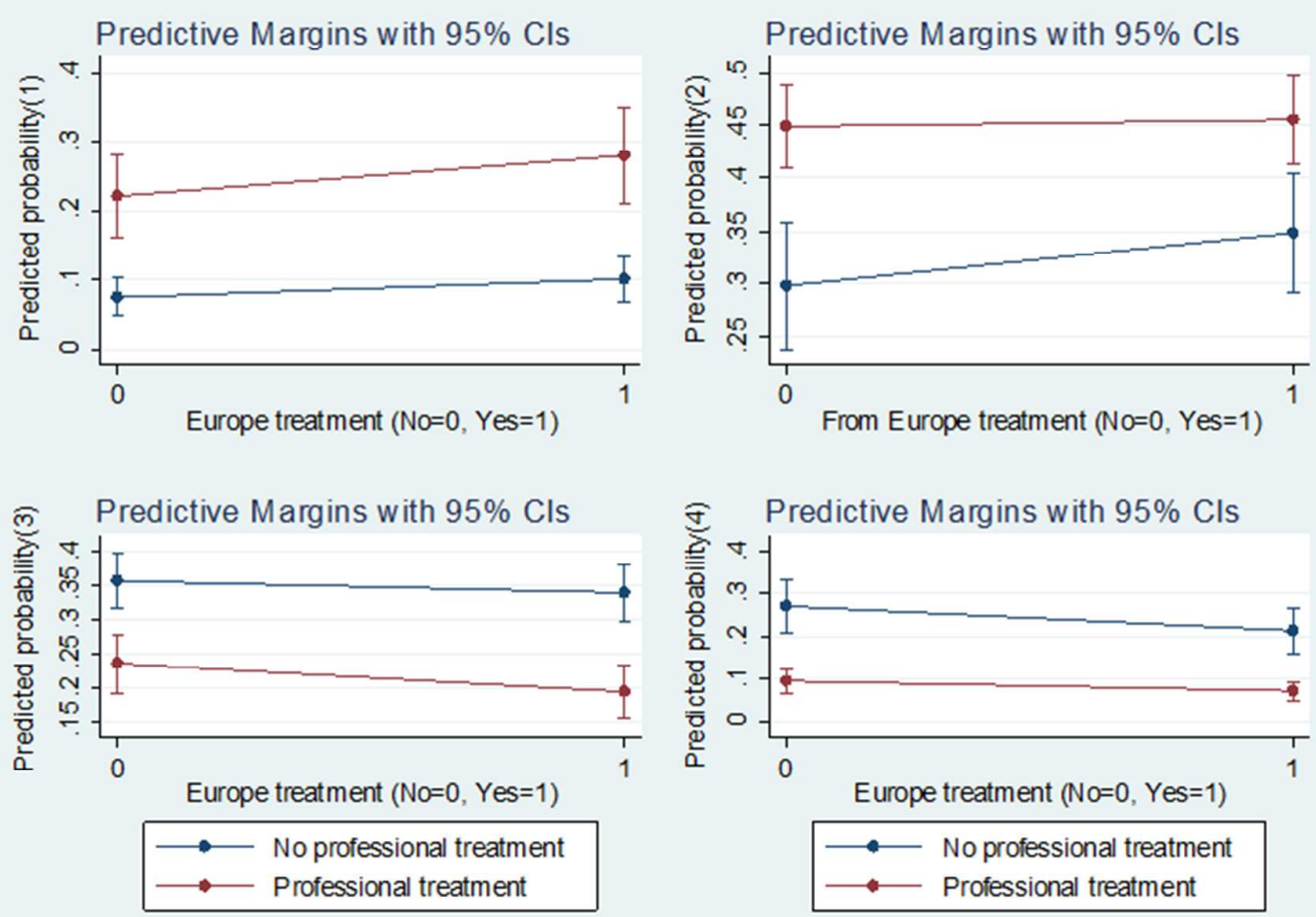

Note: predicted probabilities calculated using results from column 2 in Table 2. (1) is allow many, (2) allow some, (3) allow a few, (4) allow none. 
Figure 4: predicted probabilities of voting for the far right for different values of economic and cultural concerns over immigration

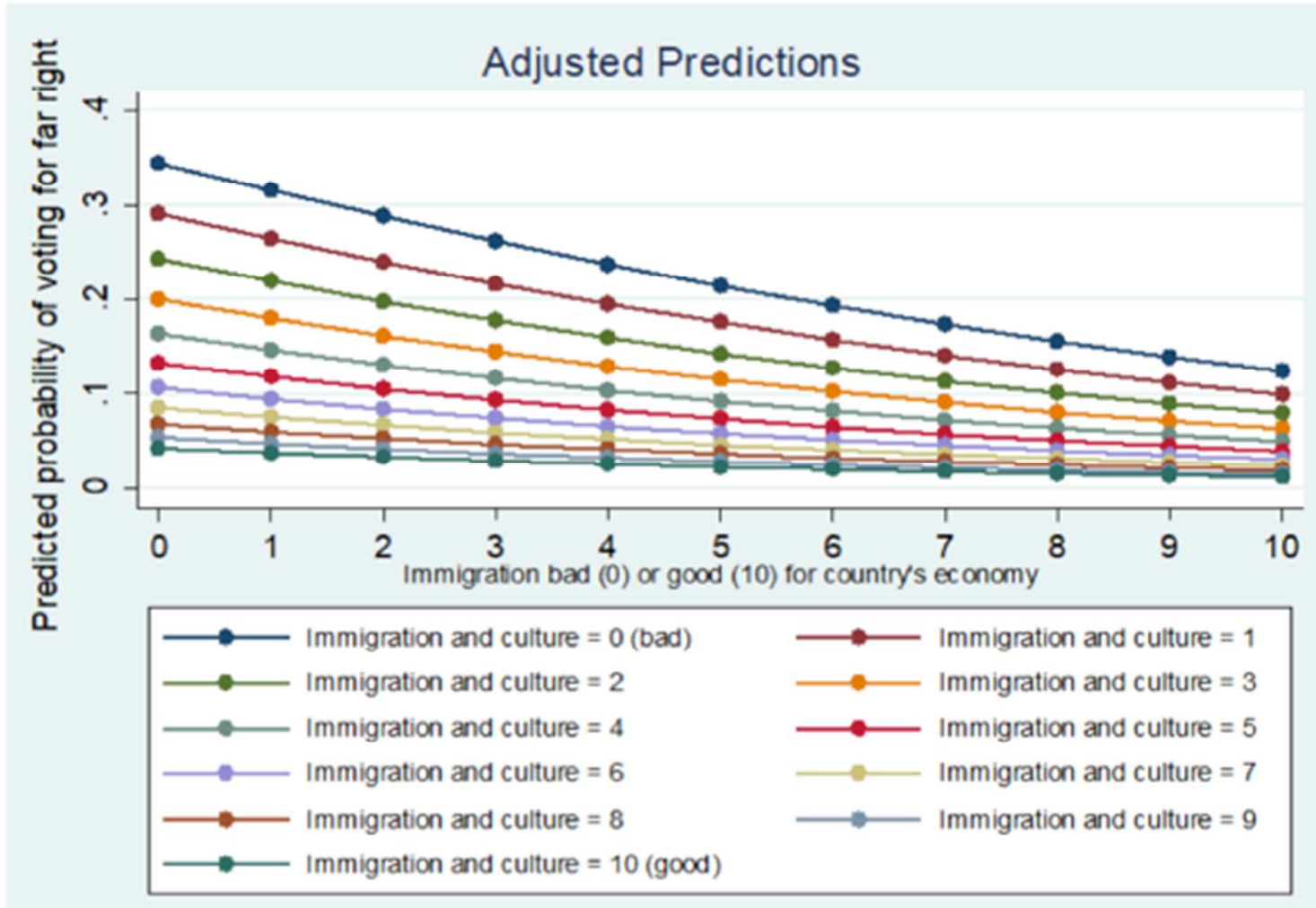




\section{Figure 5: Front National positions on welfare, planned economy and the market 1}

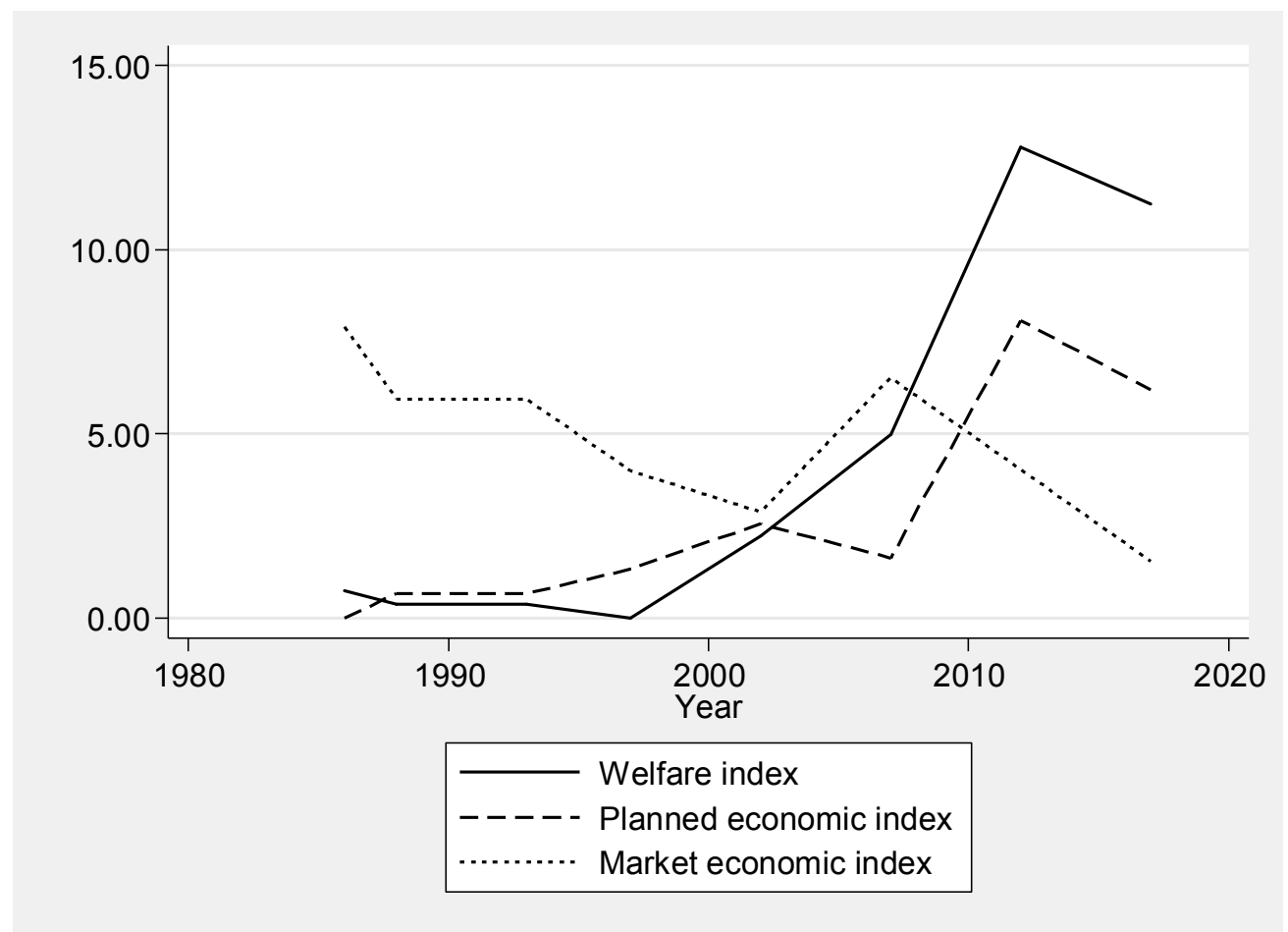

\footnotetext{
1 The 'welfare index' sums items "per503 Equality: Positive", which captures mentions of the concept of social justice and the need for fair treatment of all people; and "per504 Welfare State Expansion", which captures favourable mentions of need to introduce, maintain or expand any public social service or social security scheme. The 'planned economic index' sums items "per403 Market Regulation", which captures support for policies designed to create a fair and open economic market; "per404 Economic planning" which captures favourable mentions of longstanding economic planning by the government; and "per412 controlled Economy" which captures support for direct government control of economy. The 'market economic index' sums items "per401 Free Market Economy", which captures favourable mentions of the free market and free market capitalism as an economic model; and "per414 Economic Orthodoxy" which captures the need for economically healthy government policy making. See Volkens et al (2017) for more details on party manifesto data.
} 


\section{Figure 6: FPÖ positions on welfare, planned economy and the market ${ }^{1}$}

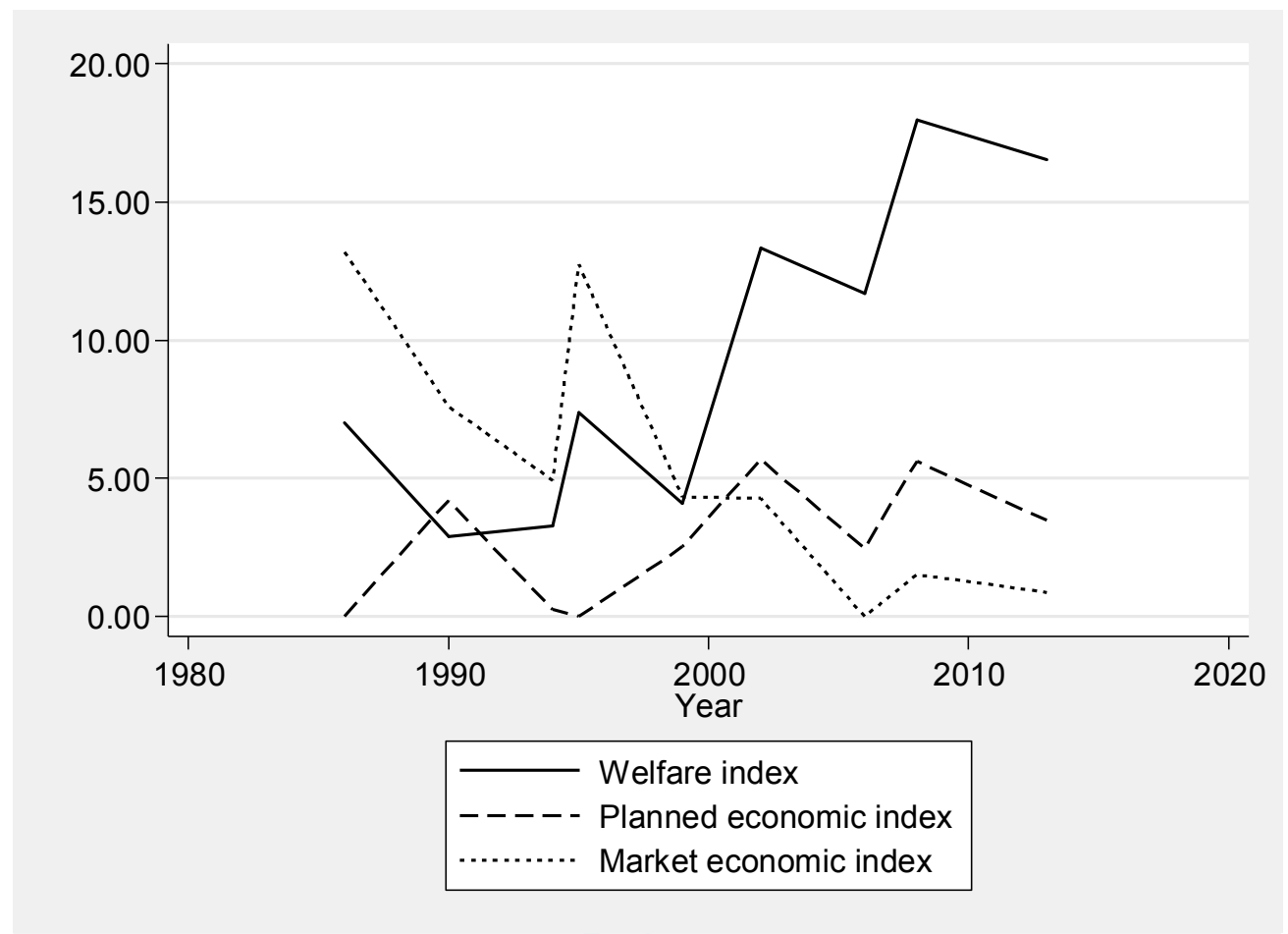

\footnotetext{
1 The 'welfare index' sums items "per503 Equality: Positive", which captures mentions of the concept of social justice and the need for fair treatment of all people; and "per504 Welfare State Expansion", which captures favourable mentions of need to introduce, maintain or expand any public social service or social security scheme. The 'planned economic index' sums items "per403 Market Regulation", which captures support for policies designed to create a fair and open economic market; "per404 Economic planning" which captures favourable mentions of longstanding economic planning by the government; and "per412 controlled Economy" which captures support for direct government control of economy. The 'market economic index' sums items "per401 Free Market Economy", which captures favourable mentions of the free market and free market capitalism as an economic model; and "per414 Economic Orthodoxy" which captures the need for economically healthy government policy making. See Volkens et al (2017) for more details on party manifesto data.
} 
Table 1: 2014 Survey Experiment in European Social Survey

\begin{tabular}{|l|l|l|}
\hline Higher economic status & $\begin{array}{l}\text { Less different ethnic origin } \\
\text { Professional migrants from } \\
\text { laropean country providing } \\
\text { origin }\end{array}$ & $\begin{array}{l}\text { Professional migrants from } \\
\text { [poor country outside Europe } \\
\text { providing largest number of } \\
\text { migrants] }\end{array}$ \\
\hline Lower economic status & $\begin{array}{l}\text { Unskilled labourers from } \\
\text { [European country providing } \\
\text { largest number of migrants] }\end{array}$ & $\begin{array}{l}\text { Unskilled labourers from } \\
\text { [poor country outside Europe } \\
\text { providing largest number of } \\
\text { migrants] }\end{array}$ \\
\hline
\end{tabular}

Note: this survey experiment was designed by Anthony Heath, Peter Schmidt, Eva Green, Alice Ramos, Eldad Davidov and Robert Ford in European Social Survey, round 7, Module on Attitudes towards Immigration and their Antecedents - Question Design Final Module in Template. London: Centre for Comparative Social Surveys, City University London. This table is reproduced from their explanatory note. 
Table 2: Results from Survey Experiment

\begin{tabular}{|c|c|c|c|c|c|c|c|}
\hline & $(1)$ & (2) & (3) & (4) & (5) & (6) & (7) \\
\hline $\begin{array}{l}\text { Model } \\
\text { Note }\end{array}$ & $\begin{array}{l}\text { Ordinal } \\
\text { logistic }\end{array}$ & $\begin{array}{l}\text { Ordinal } \\
\text { logistic }\end{array}$ & \multicolumn{3}{|c|}{\begin{tabular}{ccc}
\multicolumn{3}{c}{ Multinomial logit (ref category 'some') } \\
'allow & 'allow a & 'allow \\
many' & few' & none' \\
\end{tabular}} & $\begin{array}{l}\text { Binary } \\
\text { Logistic }\end{array}$ & $\begin{array}{l}\text { Logistic } \\
\text { Fixed } \\
\text { effects } \\
\end{array}$ \\
\hline Professional treatment & $\begin{array}{c}-1.250 * * * \\
(0.0887)\end{array}$ & $\begin{array}{c}-1.301 * * * \\
(0.0966)\end{array}$ & $\begin{array}{c}0.532 * * * \\
(0.121)\end{array}$ & $\begin{array}{c}-0.863 * * * \\
(0.0918)\end{array}$ & $\begin{array}{c}-1.856^{* * *} \\
(0.161)\end{array}$ & $\begin{array}{c}-1.504 * * * \\
(0.167)\end{array}$ & $\begin{array}{c}-1.559 * * * \\
(0.180)\end{array}$ \\
\hline Europe treatment & $\begin{array}{c}-0.311 * * * \\
(0.0640)\end{array}$ & $\begin{array}{c}-0.331 * * * \\
(0.0663)\end{array}$ & $\begin{array}{c}0.120 \\
(0.0770) \\
\end{array}$ & $\begin{array}{c}-0.233^{* * *} \\
(0.0568)\end{array}$ & $\begin{array}{c}-0.471 * * * \\
(0.0948)\end{array}$ & $\begin{array}{c}-0.267 * * * \\
(0.0780)\end{array}$ & $\begin{array}{c}-0.284 * * * \\
(0.0817)\end{array}$ \\
\hline Male & & $\begin{array}{c}-0.187 * * * \\
(0.0569)\end{array}$ & $\begin{array}{c}0.0378 \\
(0.0606)\end{array}$ & $\begin{array}{c}-0.192 * * * \\
(0.0280)\end{array}$ & $\begin{array}{c}-0.260 * * * \\
(0.0763)\end{array}$ & $\begin{array}{c}-0.163 * * \\
(0.0675)\end{array}$ & $\begin{array}{l}-0.0692 \\
(0.0553)\end{array}$ \\
\hline Age & & $\begin{array}{c}0.00343 * * \\
(0.00133)\end{array}$ & $\begin{array}{l}-0.00319 \\
(0.00207)\end{array}$ & $\begin{array}{l}-0.000528 \\
(0.00189)\end{array}$ & $\begin{array}{c}0.00598 * * * \\
(0.00226)\end{array}$ & $\begin{array}{c}0.00573 * * * \\
(0.00149)\end{array}$ & $\begin{array}{c}0.00401 * * \\
(0.00187)\end{array}$ \\
\hline Years education & & $\begin{array}{c}-0.0578 * * * \\
(0.0112)\end{array}$ & $\begin{array}{c}0.0667 * * * \\
(0.0104)\end{array}$ & $\begin{array}{l}-0.0180 * * \\
(0.00819)\end{array}$ & $\begin{array}{c}-0.0514 * * * \\
(0.0156)\end{array}$ & $\begin{array}{c}-0.0518 * * * \\
(0.0130)\end{array}$ & $\begin{array}{c}-0.0662 * * * \\
(0.00887)\end{array}$ \\
\hline House income decile & & $\begin{array}{r}-0.00155 \\
(0.0252) \\
\end{array}$ & $\begin{array}{c}0.0224 \\
(0.0167) \\
\end{array}$ & $\begin{array}{l}0.00710 \\
(0.0217) \\
\end{array}$ & $\begin{array}{c}0.0126 \\
(0.0358) \\
\end{array}$ & $\begin{array}{l}0.00852 \\
(0.0283) \\
\end{array}$ & $\begin{array}{l}-0.0117 \\
(0.0104) \\
\end{array}$ \\
\hline $\begin{array}{l}\text { Source income } \\
\text { (reference: wages) }\end{array}$ & & & & & & & \\
\hline Self-employed & & $\begin{array}{l}-0.0986 \\
(0.0888)\end{array}$ & $\begin{array}{l}0.0603 \\
(0.116)\end{array}$ & $\begin{array}{l}-0.176^{* * *} \\
(0.0851)\end{array}$ & $\begin{array}{l}-0.0374 \\
(0.133)\end{array}$ & $\begin{array}{l}0.0319 \\
(0.132)\end{array}$ & $\begin{array}{l}0.0296 \\
(0.111)\end{array}$ \\
\hline Farmer & & $\begin{array}{l}0.0460 \\
(0.124)\end{array}$ & $\begin{array}{l}-0.356 \\
(0.240)\end{array}$ & $\begin{array}{l}-0.181 \\
(0.162)\end{array}$ & $\begin{array}{c}-0.0415 \\
(0.210)\end{array}$ & $\begin{array}{l}0.0620 \\
(0.172)\end{array}$ & $\begin{array}{c}0.00870 \\
(0.152)\end{array}$ \\
\hline Pensions & & $\begin{array}{c}0.0162 \\
(0.0678)\end{array}$ & $\begin{array}{c}0.0710 \\
(0.0774)\end{array}$ & $\begin{array}{c}0.0353 \\
(0.0793)\end{array}$ & $\begin{array}{c}0.0934 \\
(0.0791)\end{array}$ & $\begin{array}{c}0.0629 \\
(0.0486)\end{array}$ & $\begin{array}{c}-0.00278 \\
(0.0483)\end{array}$ \\
\hline Unemployed & & $\begin{array}{l}0.189 * \\
(0.103)\end{array}$ & $\begin{array}{l}-0.0690 \\
(0.183)\end{array}$ & $\begin{array}{c}0.0607 \\
(0.0720)\end{array}$ & $\begin{array}{l}0.314 * * \\
(0.150)\end{array}$ & $\begin{array}{l}0.299 * \\
(0.172)\end{array}$ & $\begin{array}{c}0.232 \\
(0.161)\end{array}$ \\
\hline Other benefits & & $\begin{array}{c}0.139 \\
(0.166)\end{array}$ & $\begin{array}{c}0.248 * * * \\
(0.0704)\end{array}$ & $\begin{array}{l}0.0639 \\
(0.135)\end{array}$ & $\begin{array}{l}0.415^{*} \\
(0.213)\end{array}$ & $\begin{array}{c}0.358 * * \\
(0.165)\end{array}$ & $\begin{array}{c}0.131 \\
(0.120)\end{array}$ \\
\hline Investor & & $\begin{array}{l}-0.350 * \\
(0.182)\end{array}$ & $\begin{array}{c}0.200 \\
(0.278)\end{array}$ & $\begin{array}{l}-0.132 \\
(0.279)\end{array}$ & $\begin{array}{c}-0.647 * \\
(0.336)\end{array}$ & $\begin{array}{c}-0.620 * * \\
(0.315)\end{array}$ & $\begin{array}{c}-0.564 * * \\
(0.235)\end{array}$ \\
\hline Other sources & & $\begin{array}{l}-0.116 \\
(0.150) \\
\end{array}$ & $\begin{array}{c}0.280 \\
(0.239)\end{array}$ & $\begin{array}{l}-0.310 \\
(0.225) \\
\end{array}$ & $\begin{array}{c}0.218 \\
(0.211) \\
\end{array}$ & $\begin{array}{c}0.307 \\
(0.205) \\
\end{array}$ & $\begin{array}{c}0.232 \\
(0.198) \\
\end{array}$ \\
\hline $\begin{array}{l}\text { Occupation (reference: } \\
\text { manager) }\end{array}$ & & & & 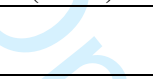 & & & \\
\hline Professional & & $\begin{array}{c}-0.242 * * * \\
(0.0668)\end{array}$ & $\begin{array}{c}0.0533 \\
(0.0890)\end{array}$ & $\begin{array}{c}-0.297 * * * \\
(0.0979)\end{array}$ & $\begin{array}{c}-0.269^{* *} \\
(0.113)\end{array}$ & $\begin{array}{c}-0.214 * * \\
(0.107)\end{array}$ & $\begin{array}{l}-0.104 \\
(0.102)\end{array}$ \\
\hline Technician & & $\begin{array}{c}0.0421 \\
(0.0789)\end{array}$ & $\begin{array}{l}-0.156 \\
(0.108)\end{array}$ & $\begin{array}{l}-0.148^{*} \\
(0.0823)\end{array}$ & $\begin{array}{c}0.0294 \\
(0.0938)\end{array}$ & $\begin{array}{c}0.0959 \\
(0.0894)\end{array}$ & $\begin{array}{c}0.177 * \\
(0.0930)\end{array}$ \\
\hline Clerical & & $\begin{array}{l}0.204 * \\
(0.104)\end{array}$ & $\begin{array}{l}-0.223 \\
(0.162)\end{array}$ & $\begin{array}{c}0.123 \\
(0.127)\end{array}$ & $\begin{array}{c}0.122 \\
(0.137)\end{array}$ & $\begin{array}{c}0.102 \\
(0.123)\end{array}$ & $\begin{array}{c}0.111 \\
(0.125)\end{array}$ \\
\hline Service & & $\begin{array}{c}0.298 * * * \\
(0.0829)\end{array}$ & $\begin{array}{c}-0.233 * * * \\
(0.0896)\end{array}$ & $\begin{array}{c}0.127 \\
(0.0894)\end{array}$ & $\begin{array}{c}0.351 * * * \\
(0.0940)\end{array}$ & $\begin{array}{c}0.317 * * * \\
(0.0888)\end{array}$ & $\begin{array}{c}0.317 * * * \\
(0.123)\end{array}$ \\
\hline Agriculture & & $\begin{array}{c}0.592 * * * \\
(0.131)\end{array}$ & $\begin{array}{l}-0.274 \\
(0.231)\end{array}$ & $\begin{array}{c}0.579 * * * \\
(0.197)\end{array}$ & $\begin{array}{c}0.746^{* * * *} \\
(0.221)\end{array}$ & $\begin{array}{c}0.433 * * * \\
(0.156)\end{array}$ & $\begin{array}{c}0.364 * * * \\
(0.114)\end{array}$ \\
\hline Craft & & $\begin{array}{c}0.618 * * * \\
(0.160)\end{array}$ & $\begin{array}{c}-0.485^{* * *} \\
(0.136)\end{array}$ & $\begin{array}{c}0.394 * * * \\
(0.139)\end{array}$ & $\begin{array}{c}0.713 * * * \\
(0.216)\end{array}$ & $\begin{array}{c}0.573 * * * \\
(0.172)\end{array}$ & $\begin{array}{c}0.487 * * * \\
(0.137)\end{array}$ \\
\hline Operator & & $\begin{array}{c}0.661 * * * \\
(0.0957)\end{array}$ & $\begin{array}{c}-0.354 * * * \\
(0.117)\end{array}$ & $\begin{array}{c}0.405 * * * \\
(0.139)\end{array}$ & $\begin{array}{c}0.854 * * * \\
(0.134)\end{array}$ & $\begin{array}{c}0.691 * * * \\
(0.121)\end{array}$ & $\begin{array}{c}0.558 * * * \\
(0.146)\end{array}$ \\
\hline Elementary & & $\begin{array}{c}0.607 * * * \\
(0.121)\end{array}$ & $\begin{array}{c}-0.289 * * \\
(0.143)\end{array}$ & $\begin{array}{c}0.327 * * * \\
(0.113)\end{array}$ & $\begin{array}{c}0.823 * * * \\
(0.161)\end{array}$ & $\begin{array}{c}0.650 * * * \\
(0.150)\end{array}$ & $\begin{array}{c}0.478^{* * * *} \\
(0.181)\end{array}$ \\
\hline Constant & Not shown & Not shown & $\begin{array}{c}-2.037 * * * \\
(0.315)\end{array}$ & $\begin{array}{l}0.440^{*} \\
(0.249)\end{array}$ & $\begin{array}{l}0.0925 \\
(0.386)\end{array}$ & $\begin{array}{c}-0.931 * * * \\
(0.332)\end{array}$ & $\begin{array}{l}-0.511 * \\
(0.264)\end{array}$ \\
\hline Country fixed effects & No & No & No & No & No & No & Yes \\
\hline Observations & 20,563 & 20,550 & 20,550 & 20,550 & 20,550 & 21,037 & 21,037 \\
\hline
\end{tabular}


Table 3: Economic and Cultural Concerns over Immigration and Far Right Voting

\begin{tabular}{|l|l|l|l|l|}
\hline & $\begin{array}{l}\text { Immigration's } \\
\text { impact on } \\
\text { economy is } \\
\text { good }(>4 \text { on } \\
10 \text { points } \\
\text { scale) }\end{array}$ & $\begin{array}{l}\text { Immigration's } \\
\text { impact on } \\
\text { economy is } \\
\text { bad }(<5 \text { on } 10 \\
\text { points scale })\end{array}$ & $\begin{array}{l}\text { Immigration's } \\
\text { impact on } \\
\text { culture is } \\
\text { good }(>4 \text { on } \\
10 \text { points } \\
\text { scale })\end{array}$ & $\begin{array}{l}\text { Immigration's } \\
\text { impact on } \\
\text { culture is bad } \\
(<5 \text { on 10 } \\
\text { points scale })\end{array}$ \\
\hline $\begin{array}{l}\text { Did not vote far } \\
\text { right }\end{array}$ & 8,707 & 3,835 & 9,828 & 2,714 \\
\hline Voted far right & $7.33 \%$ & $19 \%$ & $7.5 \%$ & $22.8 \%$ \\
\hline $\begin{array}{l}\text { Percentage voted } \\
\text { for far right }\end{array}$ & 9,396 & 4,737 & 10,619 & 3,514 \\
\hline TOTAL & 901 & 791 & 799 \\
\hline
\end{tabular}

Note: the tabulations are based on the sample average for all countries. The economic immigration attitude question ranges from 0 immigration is bad for the economy to 10 immigration is good for the economy, while the cultural immigration attitude question ranges from 0 (immigration undermines a country's culture) to 10 (immigration enriches a country's culture). Post-stratification weight including design weight were applied when calculating these averages. 